Available online at: http://e-journal.upstegal.ac.id/index.php/jip

Submit: 03-08-2017; Revision: 15-10-2017; Publish: 3o-10-2017;

\title{
KELEMBAGAAN KEBIJAKAN PARIWISATA DI LEVEL DESA
}

\author{
Yusuf Adam Hilman* \\ 1 Program Studi Ilmu Pemerintahan, Universitas Muhammadiyah Ponorogo. Jalan Budi Utomo \\ No 10 Siman Ponorogo, Jawa Timur, 63471 Indonesia. \\ * Korespondensi Penulis. E-mail: adamhilman@umpo.ac.id, Telp: +6281296125801
}

\begin{abstract}
Abstrak
Pergeseran model sistem pemerintahan dari corak sentralistik ke - desentralisasi, membawa konsekuensi pada distribusi kekuasaan hingga ke daerah - daerah, pada kajian ini, desa diberikan kesempatan untuk mengelola wilayahnya dengan berbekal dana Desa (ADD) untuk dikonversi dalam berbagai program pembangunan dan pemberdayaan masyarakat, supaya dapat mensejahterakan masyarakat. sektor yang mungkin bisa di kembangkan adalah pariwisata, mengingat secara geografis dan juga spasial desa memiliki potensi alam yang berlimpah, dan sangat potensial untuk dikembangkan. Penelitian ini bertujuan untuk mengetahui pola pelembagaan dalam pembuatan kebijakan kepariwisataan di Desa. Metode penelitian yang digunakan adalah kualitatif deskriptif, dengan teknik pengumpulan data berupa: observasi, wawancara, studi literature dan dokumentasi. Cara pelembagaan sebuah kebijakan yang baik, diantaranya harus dapat dilakukan secara bersinergi, antar lembaga dengan masyarakat melalui para steakholder atau pengambil kebijakan yang terlibat langsung, guna menemukan kemitraan dan juga pola organisasi pemerintahan yang relevan dengan kondisi desa. Relevansi konsep tersebut ditekankan pada peranan masing - masing elemen, dalam proses awal hingga akhir dalam sebuah kebijakan, sehingga dapat dipadukan dan dijalankan secara bersinergi. Selain itu, aspek transparansi, dan proses yang partisipatif harus menjadi semangat dari pembuatan kebijakan, sehingga kelembagaan yang terbentuk dapat di implementasikan secara kontekstual dengan keadaan yang diharapkan bersama.
\end{abstract}

Kata Kunci: Desentralisasi; Kelembagaan; Kebijakan Pariwisata di Desa

INTITUTION OF TOURISM POLICY IN LEVEL VILLAGE Abstract

The shift in the model of the governance system from the centralized to the decentralized style, has consequences for the distribution of power to the regions, in this study, the village is given the opportunity to manage its territory with the funds of the village (ADD), to be converted into various development programs and community empowerment, in order to make the people prosperous. Sector that may be developed are tourism, given the geographical and also spatial villages have abundant natural potential, and very potential to be developed.This study aims to determine the pattern of institutionalization in making tourism policy in the village. The research method used is qualitative descriptive, with data collection techniques such as: observation, interview, literature study and documentation. How to institutionalize a good policy, among others, should be done in synergy, between institutions and communities through the steakholder or policy makers involved directly, in order to find partnerships and also patterns of government organizations relevant to the condition of the village. The relevance of the concept is emphasized on the role of each element, in the initial process to the end in a policy, so that it can be integrated and run in synergy. In addition, aspects of transparency, and participatory processes should be the spirit of policy making, so that the institutions that are formed can be implemented contextually with the expected conditions together.

Keywords: Decentralization; Institutional; Tourism Policy; in the Vilage. 



\section{PENDAHULUAN}

Perjalanan Indonesia dalam mencari bentuk atau formulasi sistem pemerintahan, membawa pada dua model, yang pernah di terapkan, diantaranya: 1). Model sentralistik, yang menekankan pada kegiatan tata kelola pemerintahan yang lebih bersifat terpusat / tersentral di daerah perkotaan, 2). Model Desentralisasi, konsep yang kedua ini lahir dari ketidakpuasaan masyarakat di daerah terhadap sistem pemerintahan sentralistik yang dianggap tidak memberikan pemerataan terhadap kesejahteraan rakyat, maka dengan ini diperlukan upaya melakukan pendistribusian kewenaangan, agar daerah daerah memiliki porsi yang cukup dalam menyusun, merencanakan serta melaksanakan pembangunan sesuai dengan kebutuhan dan harapan masyarakat, yakni kesejahteraan dan kemandirian bangsa.

Desentralisasi atau pelimpahan wewenang yang tertuang dalam konsep otonomi daerah, jika kita pahami lebih dalam mengandung sebuah pemahaman tentang intervensi pusat guna membendung bentuk - bentuk ketidakpuasan di aras lokal, terkait bagaimana mengelola polemik tersebut supaya gejolak di daerah bisa di minimalisir, dengan mengangkat isu - isu seputar pembagian kewenangan dan kekuasaan khususnya yang berkenaan dengan disparitas pendapatan, dengan menonjolkan sistem demokrasi supaya tingkat partisipasi masyarakat menjadi lebih tinggi, sehingga gagasan Negara kesejahteraan (welfare state) bisa di sounding ke daerah (Jati 2012)
Desentralisasi merupakan salah satu bentuk perubahan atau pergeseran paradigma dalam penyelenggaraan pemerintah, bisa dijelaskan bahwa ada proses transfer kekuasaan dan kewenangan dari pemerintah pusat ke pemerintah daerah, hal ini terjadi karena luasnya urusan pemerintahan pusat, seperti yang tertuang dalam Undang Undang nomer 32 Tahun 2004 tentang Pemerintahan Daerah, kemudian muncul Peraturan Pemerintah No. 38 Tahun 2007 tentang Penyerahan Urusan Pemerintahan dari Pemerintah Kepada Pemerintah Daerah Provinsi dan Pemerintah Daerah Kabupaten / Kota sebagai paying hukumnya, tidak hanya sampai disitu, konsep desentralisasi juga di dukung dengan konsep "Money follow Function", yakni penyerahan kewenangan yang di barengi dengan perimbangan keuangan antara pusat dan daerah, ditandai dnegan munculnya UU Nomer 33 Tahun 2004 tentang perimbangan keuangan antara Pemerintah Pusat dengan pemerintahan daerah (Wasistiono, 2010).

Asumsi terkait pemberian kewenangan kepada daerah dengan model desentralisasi, atau yang lebih dikenal dengan otonomi daerah, tidak semerta - merta berjalan dengan baik, akan tetapi banyak persoalan yang kemudian muncul, ke dalam permukaan, seperti: perebutan kekuasaan didaerah, belum juga membuahkan kemakmuran dan kesejahteraan bagi masyarakat, tata kelola pemerintahan yang belum siap, konflik antar wilayah, dan masih banyak persoalan lainnya.

Penerapan otonomi daerah menimbulkan dampak yang signifikan bagi masyarakat daerah, dampak dalam bidang sosial politik adalah terjadi 
pemilihan kepala daerah langsung, munculnya elit lokal, demokratisasi. Selain dampak positif terjadi dampak negatif yaitu penyebaran korupsi dan munculnya kepala daerah sebagai raja raja kecil. Dari segi ekonomi otonomi daerah relatif dapat meningkatkan pembangunan namun masih belum mampu meningkatkan kesejahteraan masyarakat secara signifikan, pemerintahan daerah diberikan kesempatan untuk mengelola sumber sumber ekonomi yang ada di daerahnya guna meningkatkan PAD, namun PAD ini lebih banyak ditingkatkan dengan retribusi daerah.(Agus Taufik Rahman, 2011)

Seiring berjalannya pemekaran wilayah di berbagai daerah, Presiden Susilo Bambang Yudhoyono menyampaikan bahwa, perlu adanya penataan kembali konsep tersebut. hal ini di dukung oleh berbagai realitas, yang mennggambarkan sebagian besar daerah hasil pemekaran kemudian menjadi beban keuangan Negara. SBY menyebutkan dari hasil penelitian lebih dari $80 \%$ daerah yang mekar belum secara signifikan dapat meningkatkan peningkatan pembangunan di daerahnya, sehingga belum mencapai tujuan otonomi daerah, pidato ini disampaikan oleh SBY di depan siding paripurna DPR - RI pada tanggal 23 Agustus tahun 2006 (Harmantyo 2007).

Pelaksanaan otonomi daerah walaupun masih banyak menimbulkan persoalan, akan tetapi banyak segi positif yang dapat terus dipacu dan dikembangkan agar dapat menumbuhkan iklim kondusif dengan tujuan supaya bisa memperkuat daerah, khususnya desa sebagai pondasi penguatan ekonomi guna mencapai kesejahteraan (welfare state) sesuai dengan amanat konstitusi. Desa sendiri menjadi penting karena berbagai aspek yang menunjang keberadaannya, seperti faktor: historis, regulasi, dan juga potensi sumberdayanya.

Sistem pemerintahan Desa, atau yang kemudian lebih dikenal dengan sebutan "desa", dalam undang - undang 1945 (sebelum amandemen) dijelaskan dalam pasal 18, bahwa: "Dalam Teritori Negara Indonesia terdapat lebih dari 250, "Zelfbesturende landschappen" dan "Volksgemeenschappen", dengan beberapa sebutan yang berbeda - beda di daerah masing - masing, misalnya: Nagari di Padang, Banjar di Bali, Marga di Palembang, merupakan karakteristik asli (lokal) yang hingga saat ini masih bertahan, hal inilah yang kemudian disebut sebagai sebuah keistimewaan, sehingga harus diakui eksistensinya sebagai sebuah bentuk penghargaan, dan wajib diakui dan diberikan jaminan, sebagai sebuah penghormatan (Negara, 2014).

Peraturan Pemerintah Nomer 72 tahun 2015 menjelaskan tentang definisi desa sebagai: sebuah kesatuan masyarakat secara hukum yang memiliki batas - batas wilayah yang berwenang untuk mengatur dan melaksanakan kepentingan masyarakat dengan cara mengurus dirinya sendiri, berangkat dari asal usul dan adat - istiadat tersebut Negara Indonesia harus menghormatinya (Ramadana.2005).

Potensi secara kelembagaan itu diperkuat dengan adanya alokasi dana desa, yang diperuntukan bagi desa, untuk bisa dimanfaatkan sebagai instrumen untuk menciptakan kesejahteraan bagi masyarakat. 
Peraturan Pemerintah Nomor 6 Tahun 2004 tentang Dana Desa yang Bersumber Dari Anggaran Pendapatan dan Belanja Negara, menjelaskan bahwa, desa memiliki sumber dana yang kemudian di sebut sebagai Dana Desa, dana tersebut bersumber dari APBN yang peruntukannya bisa dimanfaatkan oleh desa untuk menjalankan roda pemerintahan, dan pembangunan infrastruktur desa, pemberdayaan masyarakat, demi mewujudkan kesejahteraan masyarakat. sedangkan tujuannya menurut Nurcholis (2011:89), yakni : 1. Penangangan kemiskinan dan menyelesaikan persoalan disparitas; 2 . Merencanakan penganggaran terkait program - program pembangunan yang ada di desa serta melaksanakan berbagai program pemberdayaan masyarakat; 3 . Memaksimalkan pembangunan infrastruktur pedesaan; 4. Meningkatkan pengamalan nilai-nilai yang ebrlaku di masyarkaat dalam rangka mewujudkan peningkatan kehidupan sosial; 5. Meningkatkan upaya ketentraman dan stabilitas kehidupan masyarakat; 6 . Meningkatkan pelayanan kepada masyarakat desa dalam rangka pengembangan kegiatan sosial serta kehidupan perekonomian masyarakat; 7 . Meningkatkan ketahanan sosial melalui semangat gotong royong dalam kehidupan amsyarkaat desa, 8. Optimalisasi pendapatan melalui (BUMDesa). (Riyanto 2015)

Menurut Rustiadi Pemanfaatan sumberdaya yang ada di wilayah pedesaan, dengan berbasis potensi wilayah secara optimal, bertujuan untuk mewujudkan kesejahteraan masyarakat desa, tentunya dengan cara yang berkesinambungan. Perwujudan tersebut, dilakukan dengan pengkondisian desa melalui beberapa pendekatan, diantaranya: 1). Perubahan harus disikapi dengan bijaksana, sesuai dengan kebutuhan masyarakat, agar tidak menimbulkan efek negatif; 2). Adanya komitmen bersama dalam pelaksanaan dokumen pembangunan masyarakat yang sudah disepakati. Berangkat dari kondisi tersebut maka penataan perekonomian masyarakat yang ada di wilayah pedesaan, harus terus diupayakan, supaya dapat menyelesaikan persoalan persoalan yang ada di desa. Program pembangunan melalui "Desa Membangun", banyak menekankan pada proses perencanaan yang benar - benar maksimal, sehingga dapat menjawab persoalan - persoalan yang terjadi, serta bisa memanfaatkan peluang yang ada, secara teliti, terlebih lagi kesemuanya harus menitikberatkan pada pola yang partisipatif, melaluiupaya "urun rembug" dengan seluruh pembuat kebijakan "steakholder" Yang ada di wilayah Desa (Bachrein 2010).

Undang-Undang Nomor 23 Tahun 2014 tentang Perubahan atas UndangUndang Nomor 32 Tahun 2004 tentang Pemerintahan Daerah, Dapat dikatakan, otonomi desa merupakan suatu gagasan besar dalam memberikan kesempatan yang sama kepada masyarakat untuk tumbuh dan berkembang mengikuti perubahan-perubahan baik di bidang ekonomi, politik, dan sosial budaya. Hal tersebut mengindikasikan bahwa desa harus mengambil peran yang besar secara makro ekonomi untuk memecahkan permasalahan di pedesaan yang memberikan implikasi secara mikro ekonomi (Samsir, 2016). 
Kondisi tersebut membuat desa memiliki kekuatan dalam mengembangkan wilayah, dengan dukungan landasan yuridis, modal sosial, serta anggaran dana, yang bisa dikembangkan, salah satu modelnya adalah pengembangan kepariwisataan di desa.

Secara logika pemanfaat sumberdaya secara bijaksana, bisa dilakukan melalui model pembangunan perekonomian secara berkesinambungan dan terus - menerus, peranan pemerintah tidak bisa dilepaskan dalam upaya tersebut, sebagai pembuat kebijakan "regulatur", memiliki peranan yang strategis dalam rangka untuk memaksimalkan peranserta masyarakat secara seimbang, kegiatan ekowisata merupakan upaya dalam memanfaatkan potensi lokal secara efektif, yang mencoba memadukan kegiatan wisata dengan potensi yang dimiliki oleh masyarakat. dalam rangka membuat kegiatan yang berkesinambungan, didalam aktivitas tersebut terdapat berbagai kegiatan seperti: konsevasi alam, memberdayakan ketahan ekonomi masyarakat, melalui berbagai perbedaan budaya "culture" masyarakat setempat. Berangkat dari hal tersebut kita akan dapat membayangkan model konsep Ekowisata dengan pengembangan kegiatan wisata secara konvensional. Ekowisata dijalankan secara berkesinambungan dengan menjunjung tinggi rasa cinta terhadap lingkungan. Disinilah timbul berbagai macam bentuk keuntungan antara jalannya roda perekonomian dan juga kelestarian lingkungan. Dari sudut pandang lainnya, kegiatan ini juga dapat menjaga eksistensi kearifan lokal "local wisdom" sehingga ada penghormatan terhadap hak asasi manusia. EKowisata dalam beberapa tahun terakhir berkembang karena ada kejenuhan yang melanda para wisatawan dengan model "replikatif" pariwisata yang terkesan tidak alami. Kondisi tersebut bisa dimanfaatkan oleh masyarakat untuk mengembangkan konsep pariwisata di wilayah pedesaan, karena berpotensi untuk berkembang secara pesat. (Dias Satria, 2009).

Konsep tersebut bisa kita lihat dalam beberapa contoh model pengembangan pariwisata yang ada di desa, yang sangat unik dan menjanjikan bagi masyarakat sekitar, sehingga dengan keberadaan desa wisata bisa memicu percepatan kenaikan sektor - sektor lainnya, terutama dalam hal pembangunan masyarakat dan juga perekonomiannya.

Eksistensi Dieng Plateau sebagai destinasi nasional bahkan internasional masih mampu menyedot perhatian para pelancong. Meskipun model wisata konvensional dalam bentuk "massif tourism" masih mendominasi, tetapi tidak menutup peluang menangkap pewisata minat khusus yang tertarik untuk belajar lebih dekat kehidupan masyarakat desa. Adanya motivasi dan dorongan secara kolektif dari sebagian warga di desa Dieng untuk mengelola pariwisata sebagai respon atas semakin tidak menentunya hasil dari pertanian. Ditingkat komunitas, sudah terbentuk pengelola pariwisata berbasis desa. Kajian ini pula telah melahirkan model perencanaan partisipatif yang hasilnya antara lain dipahaminya berbagai potensi dan permasalahan yang melingkupi perkembangan pariwisata di Dieng, serta diketahuinya hubungan peran dan fungsi antar lembaga yang dipandang memberi- 
kan kontribusi bagi pariwisata di Dieng Kulon khususnya dan Dieng Plateau pada umumnya (Raharjana, 2012).

Ekowisata sebagai sebuah program kepariwisataan, perlu mengingat keberadaan alam yang akan dijadikan sebagai obyek, sehingga perlu konsep keseimbangan ekosistem yang baik, guna mempertahankan keanekaragaman unsur penyusunnya. Obyek wisata Baradua berupaya untuk fokus terhadap beberapa komoditas, tidak hanya satu, dengan konsep ekology industry sehingga limbah hasil kegiatan wisata di Baradua bisa diminimalisir resiko kerusakan lingkungan yang mengancam, oleh karena itu perlu adanya perencanaan yang matang (Susetyaningsih, 2001).

Desa Bendosari yang berada di wilayah Kabupaten Malang, berupaya dengan sungguh - sungguh untuk melakukan pengembangan kegiatan kepariwisataan melalui program "Kampoeng Ekowisata", pada tahun 2010 desa ini membuat sebuah kebijakan terkait pengelolaan aktifitas perekonomian, dengan fokus beberapa bidang, seperti: pertanian, peternakan, sosial budaya, yang di branding melalui paket wisata. Pada awal perencanaan "Kampoeng Ekowisata", peranan pemerintah sangat dominan, disini desa berupaya melibatkan semua pembuat kebijakan supaya desa memiliki kapasitas yang mumpuni dalam kegiatan kepariwisataan, sehingga desa benar benar siap menjalankan program tersebut (Erlin Damayanti, Mochammad Saleh Soeaidy, 2011).

Model - model pengembangan desa wisata yang dibuat merupakan sebuah desain yang disesuaikan dengan kebutuhan masing - masing desa, namun demikian tidak semua model bisa diaplikasikan, sehingga perlu dibuat sebuah analisis secara mendalam, terkait model atau konsep desa wisata yang dapat digunakan di semua daerah, dan memiliki mekanisme atau kelembagaan yang lebih teratur dan dinamis.

Penelitian ini bertujuan untuk menganalisis serta menemukan model yang tepat terkait konsep ideal pelembagaan kebijakan pariwisata di level desa, sehingga nantinya dapat menghasilkan model kebijakaan yang efektif. oleh karena itu peneliti menitikberatkan kajian pada pola kelembagaan kebijakan pariwisata, hal ini terkait mekanisme atau dasar pembuatan kebijakan pariwisata di tingkat desa.

\section{METODE}

Jenis penelitian yang digunakan adalah kualitatif deskriptif, Pendekatan ini digunakan sebagai upaya untuk mengungkapkan fenomena secara mendalam yang digali melalui pandangan dan pengalaman masyarakat (Made Heny Urmila Dewi 2013)

Model penelitannya menggunakan studi literatur atau (Library Research), dengan cara melakukan pengumpulan data sekunder berupa hasil penelitian, jurnal, maupun naskah naskah buku, yang kemudian dilakukan identifikasi serta dilanjutkan dengan menganalisis konsep, yang menghasilkan pola ataupun skema tentang pelembagaan kebijakan pariwisata di level desa.

Secara teknis penelitian ini dilakukan dengan beberapa langkah berikut:

1) Melakukan pengumpulan data sekunder dari berbagai hasil penelitian ataupun jurnal ilmiah, dan melakukan identifikasi data yang sudah 
didapatkan, data mana yang digunakan dan mana yang tidak.

2) Melakukan kodevikasi serta penyusunan data, sesuai dengan kebutuhan peneliti.

3) Melakukan analisis data.

4) Membuat kesimpulan dari data yang sudah di susun.

5) Melakukan kritik internal dan juga eksternal, dengan cara cek sumber, dari data yang disajikan.

\section{HASIL DAN PEMBAHASAN \\ Konsep Pembangunan Desa}

Pembangunan desa yang dilakukan secara terpadu, inovatif serta kreatif, merupakan pola dari program pembangunan yang bernagkat dari proses pemetaan potensi sumberdaya alam dan masyarakat, yang akan memebentuk dan mengarahkan pada keterlibatan semua unsur atau elemen, setelah di buat sebuah perencanaan kemudian desa mencoba membuat perpaduan atau kolaborasi terhadap elemen - elemen pembuat kebijakan untuk menentukan titik temunya. Sehingga hal ini akan memperkuat kebijakan yang lahir dari kegiatan musyawarah, dan menjadi landasan pelaksanaan pembangunan yang telah disepakati (Sofianto, 2012).

Dwipayana dan Eko menjelaskan bahwa apabila konsep good governance diletakkan dalam lingkup desa maka ada dua isu strategis yang penting untuk diperhatikan. Pertama, isu pemerintahan demokratis (democratic govermance), yaitu pemerintah desa yang berasal dari partisipasi masyarakat, dikelola dengan akuntabilitas dan transparansi oleh masyarakat, dan kemudian dimanfaatkan sebaik - baiknya untuk responsivitasmasyarakat itu sendiri. Kedua, hubungan antar elemen governance di desa berdasarkan pada prinsip kesejajaran, keseimbangan, dan kepercayaan dalam melakukan pembangunan desa secara kolektif untuk mencapai kebaikan bersama (common good) (Sidik, 2015).

\section{Pariwisata di Desa}

Berangkat dari kewenangan pemerintah desa, maka di sini ada kesempatan bagi desa untuk melaksanakan pembangunan, melalui regulasi yang dapat dijalankan supaya pemerintah desa dapat membuat produk hukum, yang sesuai dengan kebutuhan, oleh sebab itu aturan - aturan yang nantinya dihasilkan bisa benar - benar jadi sebuah trobosan, untuk mengembangkan potensi desa.

Amanat Undang - Undang pasal 1, ayat (2), Nomor 6 Tahun 2014, tentang Desa, menjelaskan, bahwa, penyelenggaran urusan Pemerintahan dan kepentingan masyarakat setempat di level desa kemudian disebut pemerintah desa, disini Kepala desa dan Perangkat desa, menjalankan roda pemerintahan, berdasarkan asas - asas, diantanya: kepastian hukum, tertib penyelenggaraan pemerintahan, tertib kepentingan umum, keterbukaan, proporsionalitas, profesionalitas, akuntabilitas, efektifitas, dan efisiensi, kearifan lokal, keberagaman, dan partisipatif. Menurut Moch Solekhan pemerintah Desa berfungsi untuk melaksanakan pembangunan dan juga pembinaan terhadap kemasyarakatan, dan upaya untuk kemajuan perekonomian Desa (Queen \& Widi, 2016).

Upaya yang bisa dilakukan oleh pemerintah desa terkait pengejawanta- 
han dari salah satu fungsi yang dimiliki, bisa dilakukan melalui pengembangan dan pembinaan masyarakat di bidang kepariwisataan, hal tersebut bisa digagas di tataran desa, mengingat dalam beberapa tahun terakhir, fenomena desa wisata marak di negeri ini, kebijakan kepariwisataan lokal, bisa dilakukan melalui kebijakan - kebijakan desa, melalui pembentukan Kelompok Sadar Wisata (POKDARWIS), melalui Badan Usaha Milik Desa (BUMDes), atau melalaui karang taruna. Pada prinsipnya penyelenggaraan fungsi pemerintahan desa dalam upaya pembangunan dan juga pengembangan masyarakat di sektor pariwisata menekankan pada upaya yang terlembaga, sistematis, dan berangkat dari aspirasi atau kebutuhan di kalangan masyarakat, melalui proses penggalian potensi lokal yang identik dengan kearifan lokal, dengan cara melibatkan seluruh komponen masyarakat sehingga bersifat partisipatif. Praktik pelembagaan pariwisata di desa, nantinya akan menghasilkan sebuah kebijakan yang berkualitas, sesuai dengan harapan semua masyarakat.

Memaknai pariwisata perdesaan dengan menunjukkan suatu lingkungan geografiss tempat terjadi / berlangsungnya aktivitas pariwisata dan karakteristik asli berupa budaya tradisional, budaya pertanian, lanskap pedalaman, dan gaya hidup sederhana. Konteks ruang (space) menjadi penting untuk memosisikan aktivitas dan implikasi perkembangan pariwisata perdesaan (Raharjana, 2012).

\section{Kelembagaan pariwisata di desa}

Pengembangan desa wisata secara eksplisit menjelaskan tentang upaya kegiatan kepariwisataan yang berkaitan dengan berbagai jasa pelayanan sehingga diperlukan berbagai upaya kerjasama dengan elemen - elemen, seperti: pemerintah, swasta, dan masyarakat. Upaya membangun pariwisata dengan cara mendorong peran masyarakat menjadi hal vital (Raharjana, 2012).

Kelembagaaan pariwisata, merupakan sebuah upaya untuk memperkuat program pariwisata di desa, mulai dari proses pembuatan kebijakan, pengaturan kewenangan, sistem organisasi dan pola komunikasi elemen yang terlibat dalam teknis penyelenggaraan pariwisata di desa, kemudian dilanjutkan dengan pemetaan potensi wilayah, hingga penentuan model serta jenis wisata yang akan diterapkan, setelah itu kemudian diidentifikasi permasalahan - permasalahan yang dapat mengancam atau menggangu jalannya kepariwisataan di desa, yang terakhir yaitu proses pelaksanaan program pariwisata dan evaluasi dalam tahapan ini juga dimasukan item - item seperti publikasi dan evaluasi berkala, untuk memaksimalkan efek yang akan ditimbulkan di kemudian hari. Ada satu hal lagi yang dianggap penting, yakni soal pendanaan program pariwisata, hal ini penting, mengingat pengembangan wisata memerlukan sumber dana yang harus dikeluarkan, untuk mempersiapkan beberapa komponen pendukung atau pokok dalam sebuah desa wisata.

Melalui riset aksi ini, masyarakat Dieng Kulon diajak melakukan teknik perencanaanpartisipatif. Dua teknik yang dijalankan, yaitu (a) pemetaan partipatif (participatory mapping) dan (b) menyusun diagram venn hubungan antar - lembaga. Pada teknik pertama dimaksudkan untuk menghasilkan mapping 
yang meliputi: (i) identitikasi permasalahan, (ii) identifikasi potensi sumberdaya dan peluang pengembangannya, serta (iii) identifikasi potensi pariwisata. Metode yang diterapkan adalah dengan focus group discussion (FGD). Diskusi terfokus dilaksanakan bersama elemen masyarakat meliputi pengelola wisata, perwakilan pengurus desa, dan tokoh masyarakat. Secara gender forum ini juga dihadiri kaum perempuan dan laki - laki. Kegiatan pertemuan dijalankan secara informal dipandu fasilitator. Dalam FGD ini diawali dengan uraian maksud dan tujuan pertemuan yang disampaikan fasilitator. Target dari pertemuan ini adalah diperoleh kesadaran bersama (collectives awarness) akan potensi beserta peluang pengembangan pariwisata berbasis pedesaan yang dimungkinkan dapat dijalankan di wilayah Desa Dieng Kulon khususnya dan Dieng Plateau pada umumnya. Dari rembug bersama diperoleh informasi bahwa dibandingkan tiga empat tahun lampau, ekonomi pariwisata di Dieng Kulon baru diawali dengan beberapa homestay. Homestay merupakan salah satu sarana penunjang pariwisata yang dikelola dengan konsep community based tourism (CBT), artinya masyarakat (pemilik) secara mandiri dan swadaya menyiapkan sebagian kamar dari rumah tinggalnya sebagai tempat inap sementara. Jalinan interaksi sosial yang lebih ditekankan dibandingkan sekedar hubungan bisnis, antara tamu dan tuan rumah. Homestay yang dikembangkan dengan memanfaatkan beberapa ruang kamar untuk disewakan kepada wisatawan yang karena faktor cuaca memaksa mereka tidak mungkin melanjutkan perjalanan pulang. Daerah
Dieng Kulon hanya ada satu hotel yang berdiri, yaitu hotel Gunung Mas. Bila peak season hotel tidak sanggup menampung tamu sehingga muncul inisiatif beberapa keluarga untuk membuka rumahnya sebagai homestay.(Raharjana, 2012)

Aspek pembiayaan adalah faktor penting, sebuah keberhasilan dalam proses pelaksanaan Kebijakan Pariwisata yang menekankan pada potensi lokal "local wisdom"yang ada di Kabupaten Manggarai Barat. "pendanaan pariwisata menjadi tanggunjawab bersama Pemerintah, Pemerintah Daerah, Pengusaha, dan Masyarakat". Seperti yang tertuang dalam pasal 57 UU Pariwisata Nomer 10 Tahun 2009, Tidak hanya itu, secara tegas juga dijelaskan, bahwa "Pemerintah Daerah mengalokasikan sebagian dari pendapatan yang diperoleh dari penyelenggaraan pariwisata untuk kepentingan pelestarian alam dan budaya". Seperti yang ada dalam Pasal 59. Namun dmeikian, Praktik idealnya ternyata tidak dilakukan secara optimal, masih sangat minim, karena sumber pembiyaan masih di suplai dari dinas Kebuadayaan dan Pariwisata serta APBD (Raharjana, 2012).

Sumber dana selain dari pemerintah daerah, juga bisa berasal dari desa, mengingat desa memiliki kekuatan finansial, yang dapat dimanfaatkan untuk membantu program pariwisata yang akan digagas. Sehingga obeyek wisata yang akan dibangun tidak terkesan kurang dana dan tidak terurus, karena jika bisa dijalankan dengan maksimal, hasilnya juga akan dirasakan oleh masyarakat secara berkesinambungan.

Proses kelembagaan pariwisata di desa bisa diuraikan dengan menggunakan skemasebagai berikut: disini semua pihak 
berperan dan saling berkoordinasi, pihak - pihak yang terlibat diantaranya: Pemerintah Daerah, Pemerintahan Desa, Pemuda karang taruna, Kelompok Sadar Wisata (POKDARWIS), Media massa, Pengusaha, serta Masyarakat.

Diagram 1

Skema Kelembagaan Pariwisata Desa

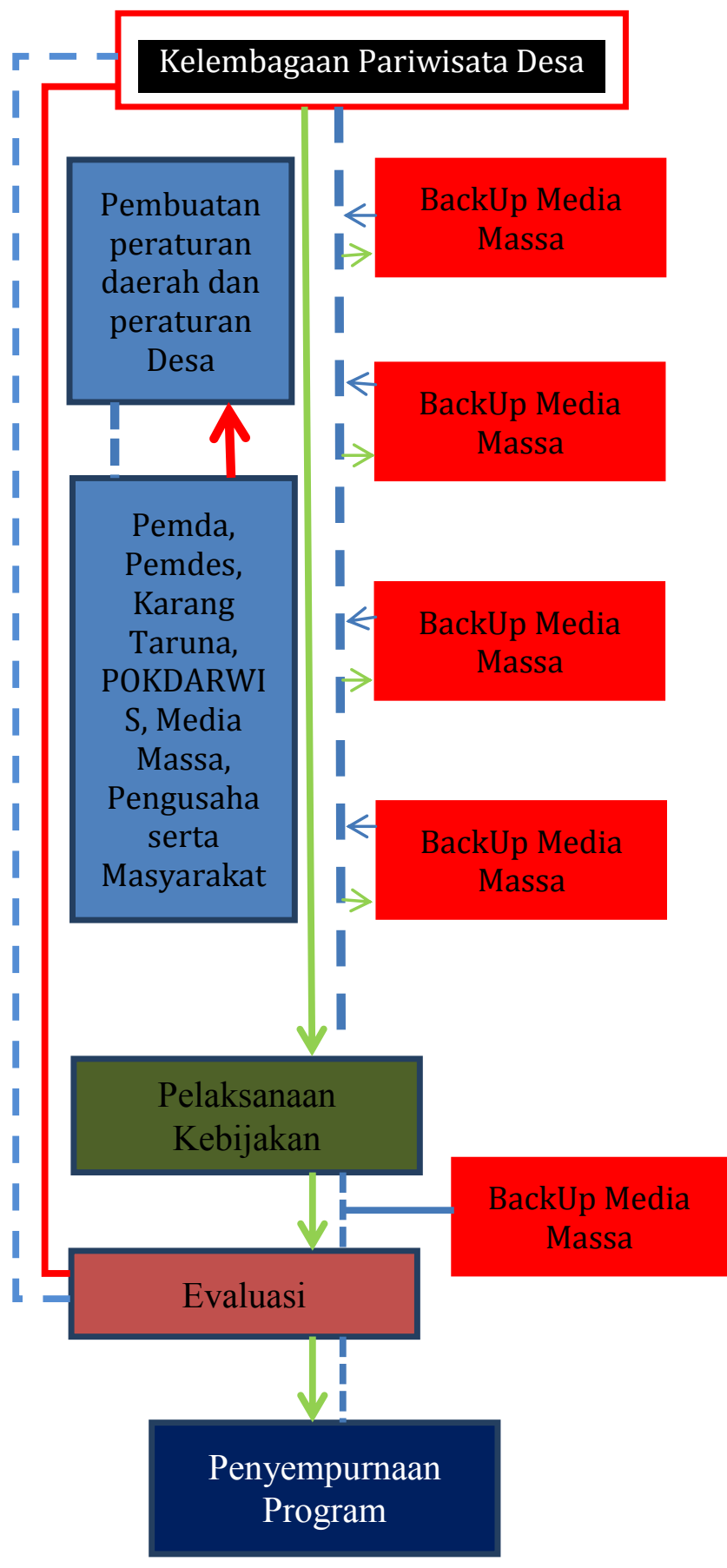

\section{Keterangan:}

: Alur Proses kelembagaan Formal ----: Alur Partisipasi

\section{Jenis - Jenis Pariwisata}

Pemahaman terkait konsep pariwisata sangat penting mengingat hal tersebut akan menjadi dasar penentuan model kepariwisataan yang akan diterapkan di sebuah desa, sehingga nantinya program desa wisata yang digalakkan akan benar - benar efesien dan efektif serta memberikan multype-effect bagi kehidupan masyarakat, untuk kehidupan yang lebih baik.

Pariwisata adalah pergerakan manusia yang bersifat sementara ke tujuan - tujuan wisata di luar tempat kerja dan tempat tinggalnya sehari - hari, dimana aktivitasnya dilaksanakan selama tinggal dalam tempat tujuan wisata, dan untuk itu disediakan fasilitas supaya dapat memenuhi kebutuhan mereka (Agung \& Djaja, 2009).

Ekowisata merupakan suatu kegiatan pariwisata yang menekankan pada konsep kelestarian sumberdaya pariwisata. Dalam perjalannya Perjalanan ekowisata lebih difokuskan padawisata alam yang bertanggung jawab dengan cara mengkonservasi lingkungan dan meningkatkan kesejahteraan masyarakat lokal. Akhir dari perjalanan ekowisata diharapkan para pengelola dan wisatawan dapat mengelola sumber wisata alam secara ramah lingkungan. (Oktavianti \& Hakim, 2013)

Menurut Murdiyanto "secara esensial desa wisata merupakan pengembangan suatu desa dengan memanfaatkan kemampuan unsur-unsur yang ada dalam masyarakat dan desa yang berfungsi sebagai atribut produk wisata menjadi satu rangkaian aktivitas pariwisata yang terpadu dan memiliki tema tertentu sesuai dengan karakteristik desa". Komponene - komponen yang 
terdapat dalam masyarakat memiliki fungsi sebagai item produk kepariwisataan, sehingga menjadi rangkaian aktivitas wisata yang terpadu sehingga menjadi karakteristik yang unik, sesuai dengan kondisi masyarakat, geografis serta sosial budaya setempat (Winasis, 2016).

Konsep Village Tourism atau Desa wisata, merupakan pengembangan sebuah wilayah yang di optimalkan sesuai dengan karakteristik yang ada sehingga menjadi sebuah produk, item tersebut yang kemudian di pasarkan secara luas dengan keutamaannya, dimana disitu terdapat kehiduapan amsyarakat pedesaan dengan segala aktifitasnya menjadi sebuah kegiatan kepariwisataan (Abdur Rohim, 2013).

Pemanfaatan desa untuk pengembangan pariwisata, dapat digambarkan sebagai proses panjang, sehingga perlu untuk memahami, potensi dan kearifan lokal yang dimiliki masing masing desa, tujuannya sebenarnya sangat sederhana, hal ini terkait dengan pemilihan atau penentuan jenis wisata di desa tersebut.

Daerah tujuan wisata yang menarik minat pengunjung, sehingga diperlukan upaya pengembangan sarana dan prasarana penunjang, sehingga terkuak beberapa alasan, diantarnaya: a). Pleasure tourism, pengunjung berorientasi untuk menikmati perjalanan sehingga mereka ketika meninggalkan rumahnya untuk kepentingan berlibur, maka akan berusaha untuk mencari udara segar sehingga ketegangan yang dirasakan bisa hilang, dengan panorama dan juga keindahan alam yang dikunjungi. b). recreation sites, mereka akan benar benar berlibur dan meninggalkan semua aktifitas kesehariannya supaya dapat memperoleh kebugaran secara fisik dan batin. c). Cultural tourism, yakni upaya wisatawan yang ingin belajar sebuah budaya, untuk tujuan pengetahuan atau menyalurkan bakat dna minatnya. d). Sport Tourism, kegiatan wisatawan yang lebih menonjolkan aktifitas untuk menjaga kebugaran dan juga mencoba hal - hal baru yang mungkin tidak terdapat di daerah asalnya. e). Business Tourism, aktifitas wisata yang dilakukan untuk kepentingan bisnis, misalnya berdagang atau untuk membeli barang - barang yang ada di suatu Negara, untuk dijual kembali kenegara asalnya. f). Conventions Tourism, jenis aktivitas pariwisata yang menekankan pada bangunan - bangunan yang menopang kegiatan pariwisata, seperti hotel dan bangunan lainnya (Susilowati.2004).

\section{Analisis Kelembagaan Kebijakan Desa Wisata}

Praktik kelembagaan kebijakan pariwisata di desa, menitikberatkan pada upaya sistematis yang terukur, dengan menekankan pada proses demokratisasi yang terukur, tentunya dengan melibatkan semua steakholder mulai dari pemerintah daerah (di level provinsi, kabupaten / kota), pemerintahan desa (karang taruna, kelompok sadar wisata, maupun Bumdes). Pengusaha, Media massa, serta masyarakat, yang dilakukan secara demokratis, untuk melahirkan sebuah kebijakan yang sinergis dan dapat diukur, sehingga kebijakan yang lahir bisa mewakili semua kepentingan steakholder, dengan tujuan untuk kemaslahatan bangsa, steakholder selain berperan dalam proses pengambilan keputusan, nantinya di tataran teknis lapangan, 
saling bahu - membahu dan bersinergi untuk saling mengontrol kegiatan desa wisata, supaya kebijakan tersebut bisa berjalan dengan optimal.

\section{SIMPULAN DAN SARAN}

\section{Simpulan}

Sistem Pemerintahan dengan model desentralisasi membentuk sebuah pola dalam ranah desa, dimana desa bisa memanfaatkan potensi dan juga modal sosial untuk mewujudkan kesejahteraan masyarakat, melalui praktik kelembagaan yakni dengan cara pembuatan kebijakan Pariwisata. Melalui sektor ini harapannya masyarakat desa bisa berdaya dan menciptakan kesejahteraan yang lebih merata.

Cara pelembagaan sebuah kebijakan yang baik, diantaranya harus dapat dilakukan secara bersinergi, antar lembaga dengan masyarkaat melalui para steakholder atau pengambil kebijakan yang terlibat langsung, guna menemukan kemitraan dan juga pola organisasi pemerintahan yang relevan dengan kondisi desa.

Relevansi konsep tersebut ditekankan pada peranan masing - masing elemen, dalam proses awal hingga akhir dalam sebuah kebijakan, sehingga dapat dipadukan dan dijalankan secara bersinergi. Selain itu, aspek transparansi, dan proses yang partisipatif harus menjadi semangat dari pembuatan kebijakan, sehingga kelembagaan yang terbentuk dapat di implementasikan secara kontekstual dengan keadaan yang diharapkan bersama.

\section{Saran}

Melihat potensi desa, saya jika tidak dimaksimalkan hal tersebut untuk melakukan praktik pembangunan di bidang pariwisata, sangat penting memahami kultur organisasi yang ada di desa, hal ini ditujukan untuk mempermudah pelaksanaan dan pembuatan program - program pengembangan desa wisata, hal ini bisa dikembangkan untuk mempermudah pola dalam melaksanakan kegiatan pariwisata di desa.

\section{DAFTAR PUSTAKA}

Abdur Rohim. Pemberdayaan Masyarakat Melalui Pengembangan Desa Wisata (Studi Di Desa Wisata Bejiharjo, Kecamatan Karangmojo, Kabupaten Gunungkidul, DIY). (Fak Dakwah dan Komun Univ Islam Negeri Sunan Kalijaga Yogyakarta. 2013).

Agung A, Djaja G. Pola Perencanaan Dan Strategi Pembangunan Wisata Ala Berkelanjutan Serta Berwawasan Lingkungan. (Bumi Lestari. 2009;9(1):121-128).

Agus Taufik Rahman. Dinamika Otonomi Daerah Di Indonesia Tahun 19452008. Skripsi Univ Negeri Jember. (Diakses dari http://repository.unej.ac.id/bitstr eam/handle/123456789/22759/ $\underline{\mathrm{K}(276) \mathrm{k} \text { 1fkip.pdf?sequence }=1.20}$ 11).

Bachrein, Saeful. "Strategi Dan Kebijakan Pembangunan Perdesaan Developing Village Approach In West Java : Rural Development Policy And Strategy." Analisis Kebijakan Pertanian, 2010: 133149.

Dias Satria. (2009) Strategi Pengembangan Ekowisata. Journal Of Indonesian Applied Economics, 3(Mei), 37-47.

Erlin Damayanti, Mochammad Saleh Soeaidy, H. R. (2011). No Title. Jurnal Administrasi Publik, 2(3), 464-470. 
Harmantyo, Djoko. "Pemekaran Daerah dan Konflik Keruangan Kebijakan Otonomi Daerah dan Implementasinya di Indonesia." Makara Sains, 2007: 16 - 22.

Jati, Wasisto Raharjo. "Inkonsistensi Paradigma Otonomi Daerah Di Indonesia: Dilema Sentralisasi Atau Desentralisasi." Konstitusi, 2012: 743 - 773.

Made Heny Urmila Dewi, Chafid Fandeli, M. Baiquni. "Pengembangan Desa Wisata Berbasis Partisipasi Masyarakat Lokal Di Desa Wisata Jatiluwih Tabanan, Bali." Kawistara, 2013: 226.

Negara S. Undang-Undang Republik Indonesia Nomor 6 Tahun 2014 Tentang Desa. (Diakses dari http://www.dpr.go.id/dokjdih/do cument/uu/UU 2014 6.pdf.2014;( 1).

Oktavianti E, Hakim L. Etnobotani Pekarangan Rumah Inap (Homestay) Di Desa Wisata Tambaksari, Purwodadi, Pasuruan, Jawa Timur. (Journal Indones Tour Dev Stud. 2013;1(1):39-45).

Queen V, Widi A. Peran Pemerintah Desa Dalam Mengelola Badan Usaha Milik Desa (Bumdes). (Jurnal Ilmu Sosial dan Ilmu Politik Univ Gadjah Mada yogyakarta. 2016;5(2):5963).

Raharjana Dt. Membangun Pariwisata Bersama Rakyat : Kajian Partisipasi Lokal Dalam Membangun Desa Wisata Di Dieng Plateau. (Kawistara. 2012;2(3):225-237).

Ramadana CB, Ribawanto H. PP No 72/2005.(Adm Publik. 2010;1(6):1068-1076).

Riyanto, Teguh. "Akuntabilitas Finansial Dalam Pengelolaan Alokasi Dana Desa (Add) di Kantor Desa Perangat Selatan Kecamatan Marangkayu Kabupaten Kutai Kartanegara." Ejournal
Administrasi Negara, 2015: 119130.

Samsir A. Studi Komperatif Model Bumdes Di Kabupaten Bantaeng. (Ad'ministrare. 2016;3:59-72).

Sidik F. Menggali Potensi Lokal Mewujudkan Kemandirian Desa. (Jurnal Kebijak Adm Publik. 2015;19(2):115-131).

Susetyaningsih A. Ekologi Industry Berbasis Daya Dukung Lingkungan Untuk Pengembangan Kawasan Wisata Agro di Desa Barudua Kecamatan Malangbong Kabupaten Garut. Kalibr STTGarut. (Diakses dari http://jurnal.sttgarut.ac.id/index.p $\mathrm{hp} /$ kalibrasi/article/download/10 8/95.2001:1-7).

Susilowati IAS dan I. Analisis Permintaan Objek Wisata Alam Curug Sewu, Kabupaten Kendal Dengan Pendekatan Travel Cost.Din Pembang. 2004;1:153-165.

Sofianto, A. (2012). Di Jawa Tengah Innovative Model of Integrated Rural Development In Central Java. Jurnal Bina Praja, 4, 251-260.

Wasistiono S. Menuju Desentralisasi Berkeseimbangan. Jurnal Ilmu Politik AIPI. (Diakses dari http://saduwasistiono.ipdn.ac.id/wpcontent/uploads/makalah-menujudesentralisasi-berkeseimbanganutk-jurnal- aipi1.pdf. 2010:1-25).

Winasis A. Efektivitas Program Pengembangan Desa Wisata Melalui Kelembagaan Dalam Peningkatan Sumber Daya Alam (SDA). JISIP Jurnal Ilmu Sos dan Ilmu Polit. 2016;5(2):12-16.

\section{PROFIL SINGKAT}

Nama Yusuf Adam Hilman, saya lahir di segala mider, 08 November 1988, saya sarjana strata S1 lulusan dari Program Studi Ilmu Pemerintahan 
Universitas Muhammadiyah Malang lulus pada tahun 2010, kemudian melanjutkan program pascasarjana di Universitas Muhammadiyah Malang mengambil magister sosiologi dan lulus pada tahun
2013, saat ini saya merupakan salah satu dosen di program studi Ilmu Pemerintahan Universitas Muhammadiyah Ponorogo. 